\title{
Woody Plant Species Diversity and Carbon Stocks Potential of Homegarden Agroforestry in Ephratana Gidimdistrict, Central Ethiopia.
}

Mesafint Minale ( $\nabla$ mesafintminale@yahoo.com )

Debreberhan Agricultural Research Center

Menale Wondie

Amhara Regional Agricultural Research Institute

\section{Research}

Keywords: Agroforestry, biomass, carbon stock, climate change, species diversity

Posted Date: December 21st, 2021

DOI: https://doi.org/10.21203/rs.3.rs-1169232/v1

License: (c) (i) This work is licensed under a Creative Commons Attribution 4.0 International License.

Read Full License 

IN EPHRATANAGIDIM DISTRICT, CENTRAL ETHIOPIA.

Mesafint Minale $^{* 1}$ and Menale Wondie ${ }^{2}$

1 Forestry research directorate, Debreberhan Agricultural Research Center, Debrebirhan, Ethiopia

*mesafintminale@yahoo.com

\section{ABSTRACT}

8 Background: Tropical agroforestry systems can contribute incredible benefit for carbon sequestration and plant diversity. This 9 system is one of the common practices in the Central part of Ethiopia. This is because of source of the multifunctional ecosystem 10 services, such as food, feed, biodiversity conservation and carbon storage potential.

11 Methodology: This study was carried out to assess the influence of land size on floristic diversity, richness and biomass carbon 12 stock. The homegardens were classified into small ( $<0.06 \mathrm{ha})$, medium $(0.06-0.1 \mathrm{ha})$ and large $(>0.1 \mathrm{ha})$. Biomass of the 13 homegarden was computed using allometric equations.

14 Results: A total of 39 woody species, belonging to 24 families were recorded in all the study homegardens. Tree density 625.8 15 tree ha- ${ }^{-1}$ and basal area $17.3 \mathrm{~m}^{2} \mathrm{ha}^{-1}$ were highest for small-size HGs. However, large homegarden had more species richness 16 (Margalef Index) per garden (12.4) compared to medium and small size homegarden. Mean biomass carbon ranged from 9 to 1789.3 ton ha- ${ }^{-1}$. Mean biomass carbon stock per unit area was higher in small homegarden $\left(49.3\right.$ ton ha $\left.{ }^{-1}\right)$ compared to medium 18 (38.4 ton ha $\left.{ }^{-1}\right)$ and large $\left(35\right.$ ton ha $\left.{ }^{-1}\right)$.

19 Conclusions: This result implies that homegarden can serve as both for carbon sequestration and conservation of woody species 20 diversity. However, a specific homegarden management plan is necessary to improve the carbon storage and species 21 diversification to the respective area. The results provide a catalyst the implication of the future potential of homegarden 22 management in carbon storage thereby for climate change adaptation and mitigation purpose. Keywords: Agroforestry; biomass; carbon stock; climate change; species diversity

\section{Background}

25 Rising levels of atmospheric carbon dioxide $\left(\mathrm{CO}_{2}\right)$ and associated greenhouse gases (GHG) are contributing to the global warming. It is becoming a central point of discussion for climate change (CC) adaption and mitigation (IPCC, 2007). The

27 increased atmospheric $\mathrm{CO}_{2}$ concentration distorts the living standard of the people and makes earth unsuitable for life (Kumar and Nair, 2011). Generally, there are signs of climate change in the world, particularly in East African countries including 
(Mesele Negash., 2013). Removing atmospheric carbon (C) and storing it within vegetation pool in terrestrial ecosystems is one of the means to mitigate GHG emissions (IPCC, 2013).

32 The world needs carbon sequestration techniques that provide social, environmental, and economic benefits while reducing atmospheric $\mathrm{CO}_{2}$ concentration (Kumar and Nair, 2011). Thus, tree-based farming (agroforestry system) is believed to be a major potential for carbon sink and could absorb large quantities of C (Kumar and Nair, 2011). Agroforestry as a land use system is getting wider recognition not only in terms of agricultural sustainability but also in issues related to CC ( Mesele Negash, 2013 ). Agroforestry systems maximize carbon stocks in the terrestrial biosphere due to diversity and management for biomass (Henry et al., 2009). The assessment report in different parts of the world including tropical regions showed that agroforestry could offer the highest C sequestration (IPCC, 2007).

The precise relation between diversity and sustainability is still heavily debated. However, home-garden agroforestry is ecologically and socio-economically sustainable due to their species diversity. A homegarden agroforestry is defined as an intensive land use system that combine diverse farming components such as annual, perennial crops and livestock that can provide environmental services, employment opportunities and household demands ((Tesfaye Abebe et al., 2005). In addition, it has a potential for $\mathrm{C}$ sequestration and thereby maintain a sound and sustainable ecology (Mohan, 2004) mainly for CC mitigation and adaptation under changing environment. This is because of the multifunctional ecosystem services and multiple arrangements of plant and relatively high species diversity compared to other agroforestry practices (Mersha Gebrehiwot, 2013). HG agroforestry could also play a significant role in adaptation and mitigation to $\mathrm{CC}$ i.e. change the microclimate, provide permanent cover, diversify the agricultural systems, improve resource use efficiency, improve soil fertility, reduce carbon emissions and increase carbon stock in the soil and biomass (Rao et al, 2007). According to studies conducted in Sub Saharan Africa homegardens is one of the land use practices suggested for $\mathrm{CC}$ adaptation and mitigation more than the monoculture practice (Asia Pacific Network for Global Change Research [APN], 2010).

51 Therefore, the introduction and development of agroforestry practices in farmlands provide multifunctional uses and are best options in the sustainable conservation mainly in agriculture dominated regions like Amhara. Specifically, information and

53 documentation on the diversity of woody plants and their relation to carbon stock potential in homegarden agroforestry systems 54 are important both to improve the income and climate change adaptation and mitigation. Farm characteristics, such as farm size,

55 shape, species adaptability, nature of cropping pattern, and management variation also affect the structure and composition in agroforestry. Few studies are conducted in relation to HG and carbon stock (Mesele Negash, 20013).

57 Most of the reports which are studied in Amhara region focus on the plant species diversity of the natural/church forests. But the 58 status of woody plant species diversity in homegarden agroforestry and their carbon stock potential is not well studied. Therefore, 
this study designed to show the contribution of traditional homegarden agroforestry of Ephratanagidim district for woody species diversity conservation and the potential role on carbon stock to use as a means for CC mitigation and adaptation strategy. The study can also be used as baseline information to understand the role of diversity on carbon stock and biomass production. The objectives of this study were to assess the current structure and composition of woody plant species and to estimate the biomass carbon stock in homegarden agroforestry.

\section{MATERIAL AND METHOD}

\section{Study Site Description}

66 The study was carried out in Ephratanagidim district, located in the central part of Ethiopia. It is geographically located between

$679^{\circ} 45^{\prime} \mathrm{N}$ to $10^{\circ} 11^{\prime} \mathrm{N}$ latitude and $39^{\circ} 43^{\prime} \mathrm{E}$ to $40^{\circ} 06^{\prime} \mathrm{E}$ longitude.

68 The study area is categorized under moist tropical climate and receives a mean annual rainfall ranging from $900-1200 \mathrm{~mm}$ with 69 considerable variation from year to year (Ephratanagidim Wereda Agricultural Office [EGWAO], 2018). The rainfall pattern is 70 bimodal, with short rain season, which is extended between March and June and long rain season between July and October. The

71 mean monthly temperature is $22^{\circ} \mathrm{C}$ with a mean monthly minimum and maximum temperatures of $11^{\circ} \mathrm{C}$ and $36^{\circ} \mathrm{C}$,

72 respectively. The altitude of the district ranges from 1200 to 2500 m.a.s.l. The major soil types of the study district are vertisol 73 (58\%), cambisol (25\%) and nitosol (17\%) (DBARC, 2016). The study area is specifically located in Yilmo Kebele (Figure 1)

\section{Sampling and Data Collection Methods}

\section{$76 \quad$ Vegetation sampling}

77 The sample was stratified according to landholding size of the HG. The HGs were categorized into three classes, i.e. small $(<$ $0.05 \mathrm{ha})$, medium (0.06 - $0.1 \mathrm{ha})$ and large (> $0.1 \mathrm{ha}$ ) based on the existing HG size. The number of samples in each land size was $10 \mathrm{HG}$. All sampled HG were between 30 and 32 years old and the size of homegardens ranged from 0.01 to 0.42 ha. All HG are located close to the homestead of the farmers. There is no sample measurement using quadrat. A complete enumeration of the woody species was carried out in each sample using the method used by (Motuma Tolera et al. 2008). However, for coffee sampling, $10 \mathrm{~m} \times 10 \mathrm{~m}$ plot was used by (Mesele Negash, 2013). The information obtained from the survey was the composition

83 of wood species, DBH, height; land size and management practices. On each HG woody species seedlings $(<2.5 \mathrm{~cm}$ diameter and

84 height $<1 \mathrm{~m})$, saplings and shrub $(2.5-5 \mathrm{~cm}$ diameter and height $1-2 \mathrm{~m})$ and trees and shrub $(\geq 5 \mathrm{~cm}$ diameter and height $\geq 2 \mathrm{~m})$

85 were recorded by complete counting method (Jiangshan et al, 2009). For the coffee shrubs, the diameter was measured at $40 \mathrm{~cm}$

86 from the ground using the method used by (Mesele Negash 2013). All tree and shrub species were recorded in their local names 87 and later the scientific names were obtained from using the books of (Azene Bekele 2007). 


\section{Methods of Data Analysis}

90 To compare woody species composition among homegarden size class, species richness (Margalef Index), Shannon diversity $\left(\mathrm{H}^{\prime}\right)$, and evenness (E) and Simpson diversity indices (D') were calculated and analyzed:

$$
H^{\prime}=-\sum_{i=1}^{n_{i=1}} \text { pi ln pi_ Equation (1) }
$$

93 Where, $H^{\prime}=$ Shannon-Wiener index of species diversity s = number of species in community pi = proportion of total abundance

94 represented by $\mathrm{i}^{\text {th }}$ species.

95 Evenness index describes the equality of species abundance in a community. Evenness (E') was calculated as:

$96 \quad E=\frac{H^{r}}{H \max }=\frac{H^{r}}{\ln S}$ with $\mathrm{H}_{\max }=\ln \mathrm{S}$ Equation (2)

97 Where; $\quad H^{\prime}=i s$ the Shannon diversity index, $S=$ is the number of species, $P i=$ is the proportion of total 98 individuals in the $\mathrm{i}^{\text {th }}$ species and $\mathrm{H} \max =\ln (\mathrm{s})$ (species diversity under maximum equitability conditions).

99 The Simpson's diversity index was derived from probability theory and it is the probability of picking two organisms at random 100 which is of different species.We get Simpson's diversity (D):

$$
D=1-\sum p_{i}^{2}
$$
Equation (3)

$$
\text { Margalef Index }=\frac{\mathrm{N}-1}{\ln (\mathrm{n})} \_ \text {Equation (4) }
$$

Where, $\mathrm{N}$ is the number of species, and $\mathrm{n}$ is the total number of individuals in the sample. will be calculated using the formula of :

$$
B A=\pi r^{2}
$$
Equation (5) 
110 The importance value index (IVI) indicates the importance of species in the system and it is calculated with three components as

111 follow:

112 Importance Value Index (IVI) for each species = RD + Rd + RF---- Equation (6)

113 Where Relative density (RD), Relative dominance (Rd) and Relative frequency (RF)

\section{Carbon Estimation}

\section{Aboveground tree biomass carbon}

The above- and belowground biomass $\left(\mathrm{Mg} \mathrm{ha}^{-1}\right)$ of woody plants for 30 homegarden was estimated using allometric equations

117 developed by Chave et al. (2005) for wet tropical woody species and Mesele Negash et al., (2013) for south-east traditional

118 agroforestry system coffee shrub in Ethiopia and Kuyah et al., 2012b. The C stocks of the tree, shrub and coffee were 119 determined. All trees and shrubs $>2.5 \mathrm{~cm}$ dbh were considered for determining above and belowground biomass, which were used 120 in estimating carbon stocks in woody species in the 30 homegarden agroforestry system. Values for wood specific density 121 were taken from the global wood density database (Zanne et al., 2009).

122 The equation developed by Chave et al. (2005):

$123 \mathrm{AGB}=\mathrm{WD} * \exp \left(-1.239+1.980 * \ln \left((\mathrm{D})+0.207 *(\ln (\mathrm{D})) 2 \_0.0281 *(\ln (\mathrm{D})) 3\right)--\right.$ Equation(7)

124 Where; AGB = above ground biomass of tree-1 $(\mathrm{kg}), \mathrm{D}=\mathrm{dbh}(\mathrm{cm})$ and $\mathrm{WD}=$ species-specific wood density in $\mathrm{g} \mathrm{cm}-3$

125 The total aboveground biomass for coffee shrub was estimated using equation developed by Mesele Negash et al., 2013 for south-east traditional agroforestry system coffee shrub in Ethiopia:

Where; $\mathrm{AGB}=$ above ground biomass of $\operatorname{tree}^{-1}(\mathrm{~kg})$ and $\mathrm{D}=\mathrm{dbh}(\mathrm{cm})$

129 Belowground biomass ( $>2 \mathrm{~cm}$ diameter) of the tree and coffee plants were calculated using the generic equation developed by (Kuyah et al., 2012b):

$\mathrm{BGB}=0.490 \mathrm{AGB}^{0.923} ; \mathrm{R}^{2}=0.95$ Equation (9)

132 Where BGB is the belowground biomass (kg dry matter/ plant) and AGB is aboveground biomass (kg dry matter/plant). For comparisons on unit area basis for each homegarden the values was extrapolated to hectare size. 
Carbon stock $=\mathrm{Y} * 0.49 \_$Equation $(10)$

Where; $\quad \mathrm{Y}=\mathrm{AGB}+\mathrm{BGB}$ tree $^{-1}(\mathrm{~kg})$.

Eventually, total woody biomass carbon stock calculated on a hectare basis.

\section{Statistical Analysis}

Prior to statistical analyses, all data were checked for meeting the assumptions of normality using Kolmogorov-Smirnov's test (and by inspecting the histogram of distribution) and homogeneity of variance using Levene's test. In cases where some assumptions (normality and/or homogeneity) were violated, log transformed data were used for the analyses. Variables were compared using one-way analysis of variance (ANOVA) following linear model (GLM) procedure at $\mathrm{P}<0.05$ with the help of

143 Statistical Package for Social Sciences (SPSS) for Window versions 16 (SPSS Inc., Chicago, USA, 2007) . If statistical significance difference were observed $\mathrm{P}<0.05$, Duncan test was used to separate means.

\section{RESULTS AND DISCUSSIONS}

\section{Woody Species Composition and Diversity four}

147 A total of 39 woody species, representing 24 families were identified and recorded in the HG agroforestry practices of the study

148 area. The result from this study showed that HG agroforestry comprised of high number of woody species compared to other land 149 uses found in and around the country. HG agroforestry has been known for its diversity, ecosystem balance, sustainability, 150 household food security and rural development (Tesfaye Abebe et al., 2005).The woody species richness of the HG agroforestry 151 was comparable with other homegarden agroforestry found in different part of Ethiopia like, (Motuma Tolera et al., 2008; Aklilu 152 Bajigo et al., 2015 and Yirefu Tefera et al., 2016). However, the woody species richness is by far lower than some sites in 153 Ethiopia. For example, 120 trees and shrubs are found from Sidama zone in Southern Ethiopia (Tesfaye Abebe et al., 2005).

154 Plantings of various exotic and native woody species in the HGs lead to higher species richness and diversification of products 155 (Figure 2).

\section{Diversity Indices}

157 Shannon diversity, Evenness and Simpson diversity index did not significantly differ among the homegarden size class, but 158 Margalef's diversity index of species richness was highly significant $(\mathrm{P}<0.001)$. The mean number of woody species per hectare 159 (ha) was 147. The maximum diversity of an individual was recorded in a large size HG and the minimum diversity was found in 
a medium homegarden (Table 1). However, large HG size planting perennial crop and tree components and livestock (Mersha Gebrehiwot, 2013) which maximize the diversity of woody species. In regarding to on species richness HGs are the highest human-made agro ecosystem next to natural forest (Kumar and Nair, 2004). This is due to selective and repeated planting and management of useful woody species from a natural regeneration (Kumar and Nair, 2004).

164 The value of described by the Shannon diversity index ( $\left.\mathrm{H}^{\prime}\right)$ for woody species was from 1.6-1.9 with the mean value 1.7 (Table 2).

165 HG agroforestry consists of a good collection of tree shrub and annual species in the Ephratana Gidm. The mean Shannon diversity index (1.7) is higher than as reported by Tesfaye Abebe et al., (2005) in Sidama village ( $\left.\mathrm{H}^{\prime}=1.41\right)$ and Bikila Mengstu and Zebene Asfaw (2016) in the Dallomena district $\left(H^{\prime}=0.47\right)$. However, lower than other countries, Keeriyagaswewa village $\left(H^{\prime}=2.13\right)$ as reported by APN (2012). In addition, the measure of evenness $(E)$ was 0.8 . This means the relative homogeneity of the species in the samples is $80 \%$. Some species are thus more abundant than others. Species evenness varied between 0.43 and 0.96 (Table 1). As the size of homegardens increased, woody species richness within homegarden size basis showed increase.

171 However, species richness ha- ${ }^{-1}$ was the highest in small sized homegardens followed by, medium sized (Table 1). In other words, species per hectare increased with increasing farm size.

\section{Woody Species Structure}

178 The Important Value Index (IVI) of all woody species in the study area is listed descending order in (Table 2). The species with the highest IVI were Coffea arabica, Cordia africana, Melia azedarach and Croton macrostachyus structuraly very important woody species in the study area. On the other hand, 6 tree/shrub species (Persea Americana, Acacia polycantha, Casuarina equisetifolia, Arundo donax, Ceiba pentandra and Commiphora africana) were found to be very rare each occurred only in one 182 of the farm plot.

The IVI is an aggregate index that summarizes the density abundance, and distribution of a species. It measures the overall importance of a species and gives an indication of the ecological success of a species in a particular area (Kent and Coker 1992). The IVI values can also be used to prioritize species for conservation, and species with high IVI value need less conservation efforts, whereas those having low IVI value need high conservation effort (Neill et al., 2001). Native tree species ranked high in terms of frequency, abundance and dominance had an importance value index in the homegarden, this support homegarden agroforestry practices are among the agroforestry systems with the potential to harbor native woody species (Kumar and Nair, 
The dominance of native species may be due to their ecological and economic importance for use as timber, the source of organic matter and income generation. This finding is in line with the reports by Ewuketu Linger (2014) which show that species with multiple uses showed higher IVI value. Similar results were reported by Yitebitu Moges (2009) from a comparison of woody species diversity along an elevation gradient in southern Ethiopia. This could be associated with their importance in improving soil fertility and high economic importance; hence the farmers prefer this tree and maintain it in their homegarden. The existence of these species in the homegarden agroforestry, that it has the advantage of conserving native species.

The structural parameters of woody species for each size class are shown in (Table 3). The three HG size class showed variations in their structural characteristics except for the dbh. The basal area and stem density were significantly affected by the size of the homegarden $(\mathrm{P}<0.05)$. However; dbh showed that there was no any significant different among homegarden size class. The mean number of stem decreased in the order Small $>$ Large $>$ Medium. The mean density of all the woody species recorded was 424 individuals per hectare (Table 3). This result showed that the density is higher than the result reported by Bikila Mengistu and Zebene Asfaw (2016) in South-East Ethiopia. Indigenous woody species accounted for $73 \%\left(24 \mathrm{~m}^{2} \mathrm{ha}^{-1}\right) \mathrm{of} \mathrm{total}$ basal area on average across all homegarden $(n=30)$. Among all homegarden, the dominant indigenous tree /shrub species were Cordia africana (mean basal area $6.71 \mathrm{~m}^{2} \mathrm{ha}^{-1}$ ) and Coffea arebica (mean basal area $6.89 \mathrm{~m}^{2} \mathrm{ha}^{-1}$ ). Similar result was reported by Mesele Negash (2013). elements within HG agroforestry are due to the the area of the homegarden. The land size strongly influenced the composition and structure of woody species. The tree density higher in small size class was may be excluding of annual crop and growing of woody species. For example, in larger HG the spatial arrangements between trees and crops were distinct. Most of the trees are planted around and close to the homestead. Low tree density is found away from the homestead. These have to be close to

211 homestead for controlling and management (Jaman et al., 2016). The mean basal area of woody species was higher than that

212 reported for Enset-coffee systems of southern Ethiopia ( (Mesele Negash, 2013). However, it is lower than that of coffee-based agro forests in Guinea (Correia et al., 2010). These difference could be the dominance of large tree species in the homegarden

214 like; Ficus species (Chave et al, 2003).

\section{Carbon Stock}

216 The mean $\mathrm{C}$ stock of total biomass (above plus below ground biomass) for the 30 sampled $\mathrm{HG}$ was $40.9 \pm 3.7$ ton $\mathrm{C}$ ha ${ }^{-1}$, mean

$217 \pm$ SE. The mean AGB carbon was 30.03 ton $\mathrm{C}^{-1}$ ha $(73.5 \%)$ and the BGB cabon was 10.82 ton $\mathrm{C}$ ha ${ }^{-1}(26.5 \%)$. Statistically there 218 were no any significance difference among homegarden size $(\mathrm{p}=0.262)$, but mean carbon stocks per unit area was slightly higher 219 in the small HG (49.3 \pm 8.1 ton $\left.\mathrm{C} \mathrm{ha}^{-1}\right)$. The mean carbon stock for medium and large size $\mathrm{HG}$ was $38.4 \pm 6.4$ ton $\mathrm{C}$ ha ${ }^{-1}$ and $35 \pm 3.3$ 
ton $\mathrm{C} \mathrm{ha}^{-1}$, respectively (Figure 6). The small homegarden relatively higher may be as result of large basal area and tree density

221 (Kumar and Nair, 2004). This result is in contrary to the study of Kumar and Nair (2011). The smaller size HG had higher

222 biomass and carbon stock than medium and large. This may be due to the intensive management of farm plots by the farmers of

223 Yilmo Kebele.

224 The total biomass $\mathrm{C}$ stocks of the HG agroforestry in Ephratanagidim ranges 35- 49.3 ton $\mathrm{C}^{-1}$ (Figure 3). And the average

225 aboveground $\mathrm{C}$ storage potential of agroforestry systems in semiarid, sub-humid, humid and temperate regions has been

226 estimated to be 9, 21, 50 and 63 ton $\mathrm{C} \mathrm{ha}^{-1}$, respectively (Montagnini and Nair, 2004). The mean carbon stock substantially lower

227 than the range reported from the Bangladesh and Indonesia, which ranges from 6.25- 193.83 ton $\mathrm{C}$ ha ${ }^{-1}$ (Jaman et al., 2016) and

228 30- 123 ton $\mathrm{C}^{-1}{ }^{-1}$ (Roshetko et al., 2002a). However, the carbon stock of HG of Ephratanagidim is higher than the HG of

229 Woleyata 15 ton $\mathrm{C} \mathrm{ha}^{-1}$ as reported by (Aklilu Bajigo et al. 2015). The HG from Sri Lanka which is the tropical region is 13 ton C

$230 \mathrm{ha}^{-1}$ (Mattsson et al. 2014). This difference is due to the difference in the amount of trees in the agroforestry systems. And it

231 could be variability of model use for biomass estimation (Sileshi, 2014).

\section{Relationship between diversity and carbon stocks}

233 A correlation analysis was conducted by using AGB carbon with selected diversity parameters and HG size measures from 30 of

234 HG (Table 4). There were significant correlation between the AGB carbon and the stand characters (i.e., Basal area ha ${ }^{-1}$, Trees

235 density ha ${ }^{-1}$, Shannon index H' and DBH). Even though statistically not significant, the HG size has a negative correlation in

236 carbon stock. The larger the HG size the lesser the carbon stock per unit area due to small basal area and low stem density (Table

$2374)$

238 Basal area is significantly correlated to AGB carbon stock $(\mathrm{r}=0.89 ; \mathrm{P}<0.001)$ than number of species and Shannon $\left(\mathrm{H}^{\prime}\right)$ indices

239 with $(\mathrm{r}=0.11 ; \mathrm{P}>0.05$ and $\mathrm{r}=0.29 ; \mathrm{P}>0.05)$ respectively. Similar result is reported by Jaman et al. (2016) from quantification of

240 carbon stock and tree diversity of HG in Rangpur district, Bangladesh where basal area is strongly affect carbon stock potential

241 of homegarden agroforestry. Tree density of the study area varied from 115.7 to 1301.6 per hectare (9-95 trees per homegarden).

242 Correlation analysis showed a positive and significant relationship between tree density and carbon stock where $(r=0.39 ; \mathrm{p}<0.01)$

243 (Table 7). Tree density is an important factor to store carbon as it directly relates to the carbon stock (Roshetko et al., 2002a).

244 Considering the relationship between tree density and biomass carbon stock it is indicated that tree density is a strong

245 determinant factor of aboveground carbon stock. Diameter at breast height is also a strong determinant factor which is

246 significantly affecting carbon stock potential of homegarden agroforestry $(\mathrm{r}=0.66, \mathrm{p}<0.001)$; similar result reported by (Mattsson

247 et al., 2014). 
249 The experiences of establishing HG by the farmers' of Ephratanagidim are not only to optimize food production and sustainable

250 land management, but are also important for conserving indigenous species, optimizing biomass and improving carbon stock, this

251 in turn contributes to climate change adaptation and mitigation. The HG also conserves indigenous species such as, Commiphora

252 Africana, Cordia africana, C. macrostachyus, Ehretia cymosa and Prunus africana. The woody plant species evenness and

253 diversity index's were not affected by homegarden size.

254 The results suggested that homegarden size was not the factor for AGB carbon stock however, the investigated homegardens in 255 the study area hold a wide range of carbon between 9 to 89.3 ton ha ${ }^{-1}$ and a mean above-below ground biomass $\mathrm{C}$ stock of 41.4

256 ton $\mathrm{C} \mathrm{ha}^{-1}$, which is higher than other reported carbon estimates for homegardens in different ecological zones and equaling the amount of C stored in other tree-based systems. The carbon estimates found here are reflecting the differences in tree density, tree diversity and management practices between individual homegardens. In addition, there were strong and positive interaction between AGB carbon and HG basal area of trees/shrubs. Homegarden with large basal area retained more carbon in their biomass compared to those with small basal area.

The finding of the present study revealed that homegardens should be established by maintaining proper species composition model focusing on the diversity of tree species so that it sequester a substantial amount of carbon and contribute to the global climate change mitigation. The results of this study show that the investigated homegardens have a good capacity for carbon storage capacity which provides useful information for the national process of whether homegardens should be considered to be included as an activity within Ethiopia commenced National Programme on REDD ${ }^{+}$. In addition, the study suggested timely and appropriate mechanism to explore the CDM/ REDD investment on smallholder farmers can access international $\mathrm{C}$ investment funds to convert low-biomass lands.

List of abbreviations: AGB: above ground biomass; BGB: belowground biomass; C: carbon; CDM: Clean Development Mechanism; DBARC: Debre Birhan Agricultural Research Center; CO2e: Carbon dioxide equivalent; DBH: Diameter at Breast Height; EGWAO: Ephratana Gidm Wereda Agriculture Office; HG: homegarden; IPCC: Intergovernmental Panel on Climate Change; IVI: Important Value Index; REDD+: Reducing Emissions from Deforestation and Forest Degradation.

272 Funding: The study was funded by Amhara Region Agricultural Research Institute (ARARI), Ethiopia

273 Conflict interests: The authors declare that they have no conflict of interests.

274 Acknowledgements: I would like to express my deepest gratitude and sincere thanks to my advisor Dr.Menale Wondie whose guidance, constructive comments and suggestions have been highly invaluable for the completion of the study. I am particularly grateful for their cooperation Ephratana gidm district, Agriculture and Rural Development Bureau. Special thanks go to farmers who allowed me to collect samples from their farmlands. I offer my regards to all institutions and individuals who supported me in any way during the entire period of my study. 
Authors' contribution: Mesafint Minale, designed and conducted the experiments at field, data collection, analysis, interpret the results and finally prepared the draft manuscript. Menale Wondie, designed the experiments, interpret the results, review the full manuscript and improve the contents of these manuscripts. All authors read and approved the final manuscript. Availability of data and materials: The datasets used and/or analyzed during the current study are available from the corresponding author on reasonable request.

Ethics approval and consent to participate: Not applicable.

\section{REFERENCES}

Aklilu Bajigo, Mikrewongel Tadesse, Yitebitu Moges and Agena Anjulo (2015b) Estimation of Carbon Stored in Agroforestry Practices in Gununo Watershed, Wolayitta Zone, Ethiopia.

Asian Pacific Network for Global Change Research (APN) Final report (2010) Vulnerability of Home-garden Systems to Climate Change and its Impacts on Food Security in South Asia.

Azene Bekele (2007) Useful trees and shrubs for Ethiopia. Identification, propagation and management for 17 agroclimatic zones. world agroforestry centre, East Africa region, Nairobi, Kenya.

Bikila Mengistu and Zebene Asfaw (2016) Woody Species Diversity and Structure of Agroforestry and Adjacent Land Uses in Dallo Mena District, South-East Ethiopia

Chave J., Andalo C., Brown S., Cairns M.., Chambers J., Eamus D., Fölster H., Fromard F., Higuchi N., Kira T., Lescure J.,

Correia M., Diabaté M., Beavogu P., Guilavogui K., Lamanda N. and De Foresta, H. (2010) Conserving forest tree diversity in 1747.

EGWAO. (2018) Ephratanagidim Woreda Agricultural Office planning section report (unpublished).

Ewuketu Linger (2014) Agro-ecosystem and socio-economic role of homegarden agroforestry in Jabithenan District, NorthWestern Ethiopia: implication for climate change adaptation. Linger Springer Plus, 3:154.

Getahun Haile, Mulugeta Lemenih, Feyera Senbeta and Fisseha Itanna (2016) Plant diversity and determinant factors across smallholder agricultural management units in Central Ethiopia. Agroforest Syst.

Henry M., Tittonell P., Manlay R., Bernoux M. and Albrecht A. (2009) Biodiversity, carbon stocks and sequestration potential in aboveground biomass in smallholder farming systems of western Kenya. Agriculture, Ecosystems and Environment 129: 238-252. 
IPCC. (2006) IPCC Guidelines for National Greenhouse Gas Inventories. In H.S. Eggleston, L. Buendia, K. Miwa, T. Ngara \& K. Tanabe (Eds.), IPCC National Greenhouse Gas Inventories Programme Institute for Global Environmental Strategies, Japan.

IPCC. (2007) Highlights from Climate Change. The Physical Science Basis: Summary for Policy Makers. Contribution of Working Group I to the Fourth Assessment Report of the Intergovernmental Panel on Climate Change. Cabridge University Press, Institute of Terrestrial Ecology, Edinburgh, pp. 545-552.

IPCC. (2013) Summary for Policymakers. In: Climate Change. 2013. The Physical Science Basis. Contribution of Working Group I to the Fifth Assessment Report of the Intergovernmental Panel on Climate Change [Stocker, T.F., D. Qin, G.-K. Plattner, M. Tignor, S.K. Allen, J. Boschung, A. Nauels, Y. Xia, V. Bex and P.M. Midgley (eds.)]. Cambridge University Press, Cambridge, United Kingdom and New York, NY, USA.

Jaman M.S., Hossain M.F., Shariful Md., Helal M. G. J., Mahbuba J. (2016) Quantification of Carbon Stock and Tree Diversity of Homegardens in Rangpur District, Bangladesh. International Journal of Agriculture and Forestry 2016, 6(5): 169-180.

Jiangshan L., Xiangcheng M., Haiba R. and Keping M. (2009). Species-Habitat Associations Change in Subtropical Forest of China. Journal of Vegetation Science, 20, 415-423.

Kent M. and Coker P. (1992) Vegetation Description and Analysis: A Practical Approach, Belhaven Press, London, UK.

Kumar B.M. and Nair P.K.R. (2004) The enigma of tropical homegardens. Agroforest Syst 61: 135 - 152.

Kumar B.M. and Nair P.K.R. (2011) Carbon Sequestration Potential of Agroforestry Systems: Opportunities and Challenges. Springer Science+ Business Media 8: 326.

Kuyah S., Dietz J., Catherine M., Jamnadassa R., Mwangi P., Coe R. \& Neufeldt H. (2012b) Allometric equations for estimating biomass in agricultural landscapes: II. Belowground biomass. Agriculture, Ecosystems and Environment 158:225-234

Mattsson E., Ostwald O., Nissank S.P., and Pushpakumara D.K.N.G . ( 2014) Quantification of carbon stock and tree diversity of homegardens in a dry zone area of Moneragala District, Sri Lanka.

Mersha Gebrehiwot (2013) Recent Transitions in Ethiopian Homegarden Agroforestry: Driving Forces and Changing Gender Relations, Licentiate Thesis Swedish University of Agricultural Sciences Umeå.

Mesele Negash (2013) The indigenous agroforestry systems of the south-eastern Rift Valley escarpment, Ethiopia: Their biodiversity, carbon stocks, and litter fall. Doctoral Thesis, department of Forest Sciences, Faculty of Agriculture and Forestry University of Helsinki, Tropical forest report.

Montagnini, F. and Nair, P.K.R. (2004) Carbon sequestration: an under environmental benefits of agroforestry systems. Agroforestry Systems 61:281-295.

Motuma Tolera, Zebene Asfaw, Mulugeta Lemineh and Erik K. (2008) Woody species diversity in a changing landscape in the south-central highlands of Ethiopia. Agriculture, Ecosystems and Environment 128: 52-58. 
Neill G. A. O, Dawson I. K. and Sotelo-Montes C. (2001) "Strategies for genetic conservation of trees in the Peruvian Amazon basin," Biodiversity and Conservation, vol. 10, no. 6, pp. 837-850.

Rao K.P.C., Verchot L. and Laarman J. (2007) Adaptation to Climate Change through Sustainable Management. Open Access Journal published by International Crops Research Institute for the Semi-Arid Tropics (ICRISAT).

344 Roshetko M., Delaney M., Hairiah K., and Purnomosidhi P. (2002a) Carbon stocks in Indonesian homegarden systems: can smallholder systems be targated for increased carbon storage? American J. Altern. Agric. (17), 125- 137.

Sileshi G.W. (2014) A critical review of forest biomass estimation models, common mistakes and corrective measures. For Ecol Manage 329:237-254.

Tesfaye Abebe, Wiersum K.F., Bongers F. and Sterck F. (2005) Diversity and dynamics in homegardens of southern Ethiopia. $\mathrm{PhD}$ thesis Wageningen University.

Yirefu Tefera, Wendawek Abebe and Bogale Teferi. (2016) Woody Plants Species Diversity of Homegarden Agroforestry in three Agroecological Zones of Dilla Zuria District, Gedeo Zone, Southern Ethiopia International Journal of Fauna and Biological Studies; 3(3): 98-106.

Yitebitu Moges. (2009) The impact of overstorey trees on sustainable coffee (Coffea arabica L.) Production in southern Ethiopia. Ph.D Dissertation, Horizonte Bd. 25, Der Andere Verlag, Tönning, Lübeck and Marburg.

Zanne A.E., Lopez-Gonzalez G., Coomes D.A., Ilic J., Jansen S., Lewis S.L., Miller R.B., Swenson N.G., Wiemann M.C., Chave 


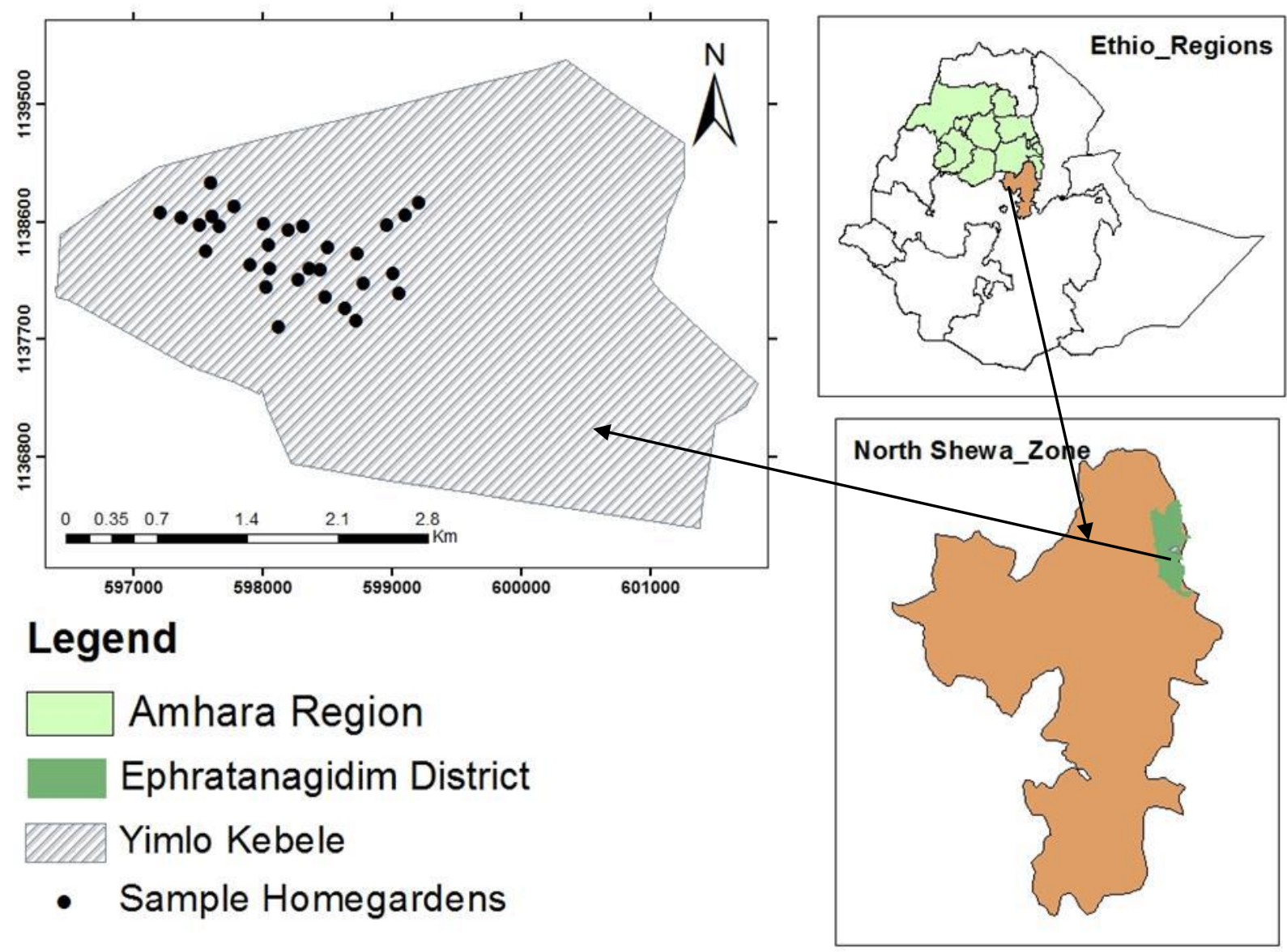

$364 \quad$ Fig 1 location of the study area

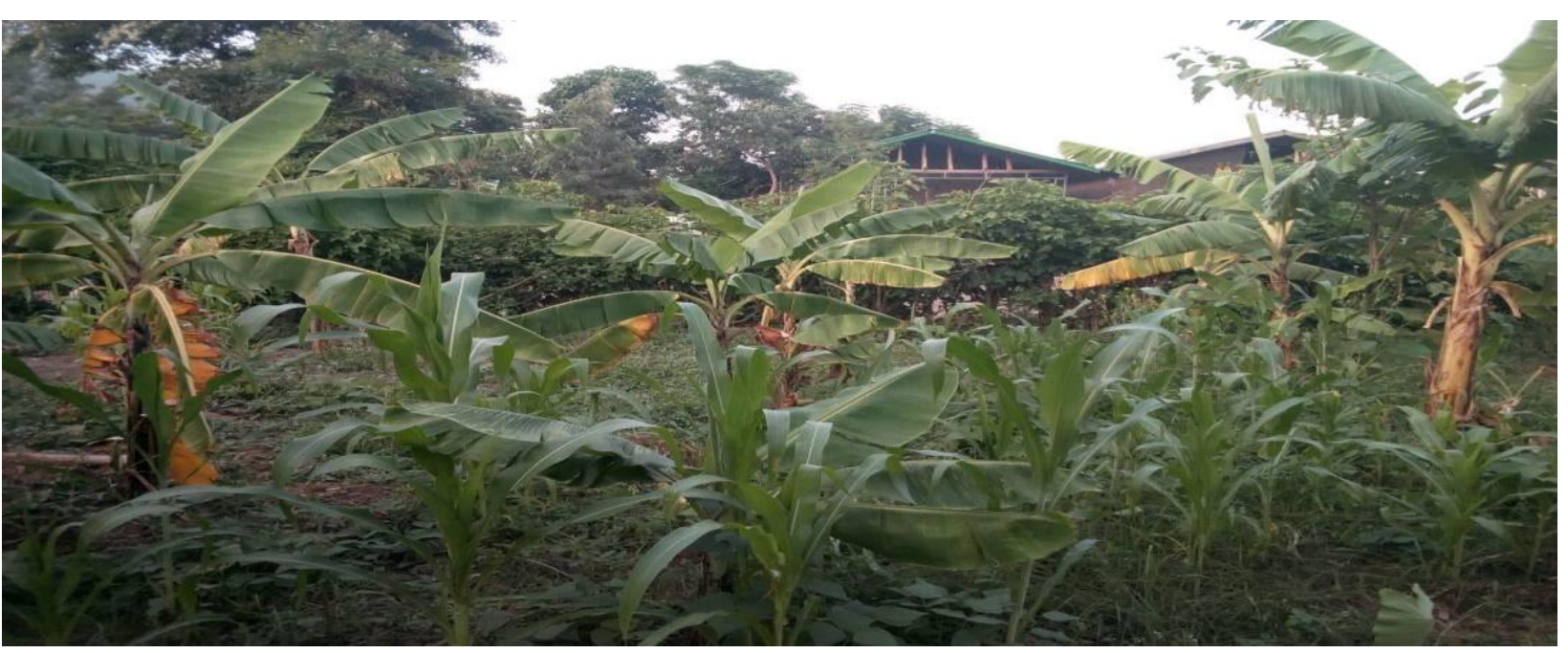

Fig 2 Homegarden agroforestry with different strata's. 


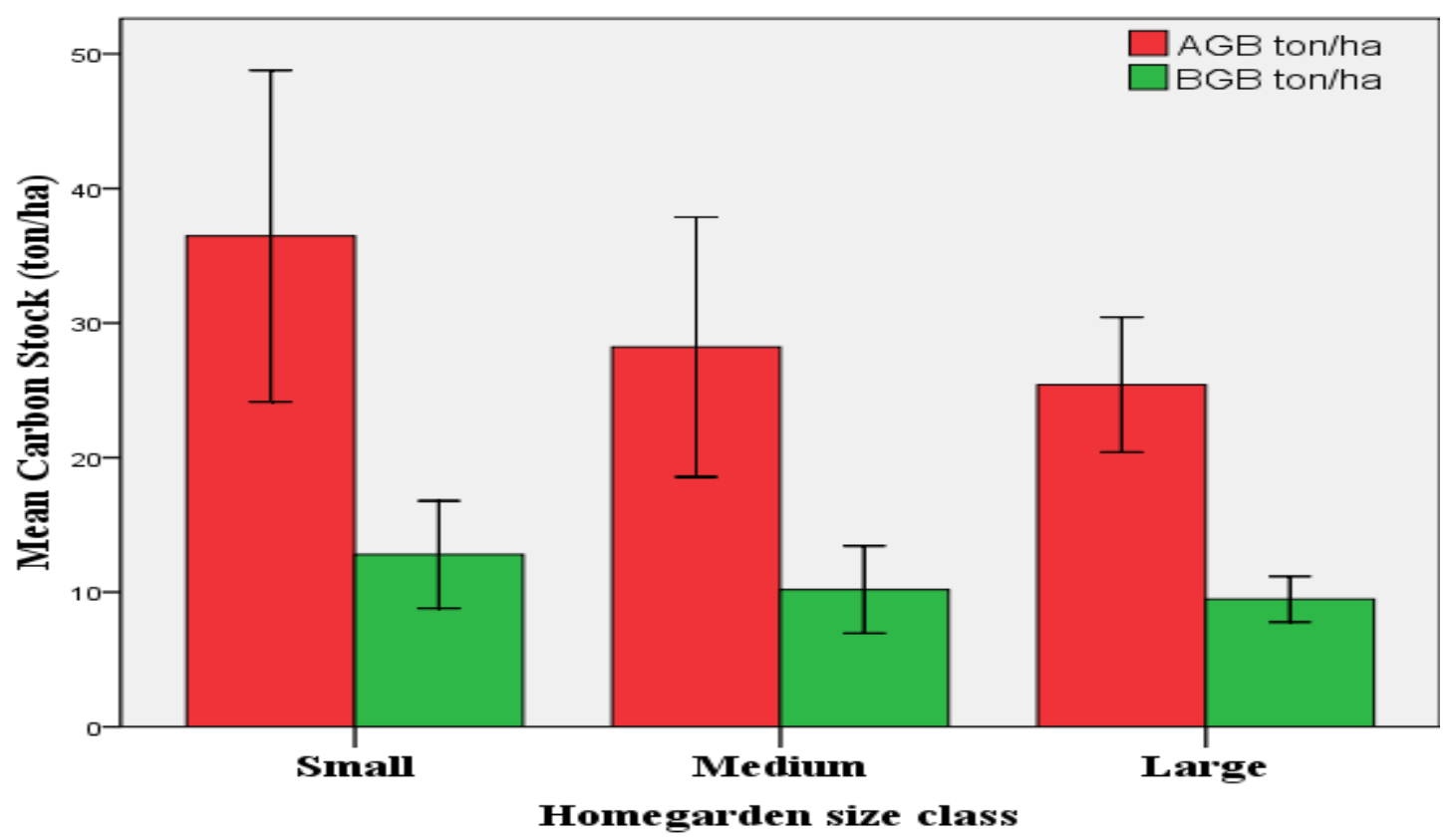

Figure 3 Above and below ground carbon stock in the three homegarden sizes. Error bar show the standard error.

Table 1 Mean woody species Shannon index, Shannon evenness, Simpson's index of diversity, Margalef's index and number of species.

\begin{tabular}{llllll}
\hline Homegarden & $\mathrm{H}^{\prime}$ & $\mathrm{E}$ & 1-D & MI & No. of species ha $^{-1}$ \\
Class & & & & & \\
\hline Small & $1.8(0.08)$ & $0.85(0.02)$ & $0.78(0.02)$ & $8.3(0.7)^{\mathrm{b}}$ & $261(37)^{\mathrm{a}}$ \\
Medium & $1.6(0.1)$ & $0.79(0.05)$ & $0.75(0.03)$ & $7.3(0.5)^{\mathrm{b}}$ & $102(8)^{\mathrm{b}}$ \\
Large & $1.9(0.2)$ & $0.76(0.04)$ & $0.75(0.05)$ & $12.4(1.0)^{\mathrm{a}}$ & $80(11)^{\mathrm{b}}$ \\
Overall mean & $1.7(0.07)$ & $0.8(0.03)$ & $0.76(0.02)$ & $9.1(0.6)$ & $147(20)$ \\
P_value & $\mathrm{Ns}$ & $\mathrm{Ns}$ & $\mathrm{Ns}$ & $<0.001$ & $<0.001$
\end{tabular}

$\mathrm{RD}(\%)$

IVI

density/ha 


\begin{tabular}{|c|c|c|c|c|c|}
\hline Coffea Arabica & 9.12 & 67.42 & 21.00 & 97.54 & 685 \\
\hline Cordia Africana & 7.77 & 4.45 & 20.46 & 32.68 & 45 \\
\hline Melia azedarach & 9.46 & 3.49 & 9.37 & 22.32 & 35 \\
\hline Croton macrostchyus & 8.11 & 1.44 & 5.20 & 14.75 & 15 \\
\hline Eucalyptus camaldulensis & 4.39 & 3.94 & 6.25 & 14.59 & 40 \\
\hline Ficus sur & 2.70 & 0.48 & 7.44 & 10.62 & 5 \\
\hline Ehretia cymosa & 5.74 & 1.74 & 3.07 & 10.56 & 18 \\
\hline Acacia nilotica & 2.03 & 2.38 & 4.30 & 8.70 & 24 \\
\hline Ficus sycomorus & 2.70 & 0.30 & 4.92 & 7.92 & 3 \\
\hline Prunus africana & 5.41 & 1.41 & 0.47 & 7.29 & 14 \\
\hline Combretum molle & 0.68 & 0.15 & 6.31 & 7.13 & 2 \\
\hline Calpurina aurea & 4.39 & 2.20 & 0.32 & 6.91 & 22 \\
\hline Mangifera indica & 2.70 & 1.59 & 1.79 & 6.08 & 16 \\
\hline Grewia bicolor & 3.72 & 0.51 & 1.73 & 5.95 & 5 \\
\hline Citrus aurantifolia & 3.38 & 0.57 & 0.22 & 4.17 & 6 \\
\hline Jatropha carcus & 2.03 & 1.50 & 0.22 & 3.75 & 15 \\
\hline Carica papaya & 2.36 & 0.72 & 0.56 & 3.65 & 7 \\
\hline Rhamnus prinoides & 1.35 & 1.74 & 0.00 & 3.10 & 18 \\
\hline Olea europaea & 2.03 & 0.33 & 0.72 & 3.07 & 3 \\
\hline Ziziphus spina-christi & 1.35 & 0.15 & 1.20 & 2.71 & 2 \\
\hline Citrus sinensis & 2.03 & 0.24 & 0.23 & 2.50 & 2 \\
\hline Ziziphus mucronata & 2.03 & 0.21 & 0.13 & 2.37 & 2 \\
\hline Leucaena leucocephala & 1.69 & 0.27 & 0.38 & 2.34 & 3 \\
\hline Psidium guajava & 1.35 & 0.39 & 0.41 & 2.16 & 4 \\
\hline Ricinus communis & 1.35 & 0.36 & 0.30 & 2.01 & 4 \\
\hline Jacaranda mimosifolia & 1.35 & 0.12 & 0.38 & 1.85 & 1 \\
\hline Celtis africana & 1.35 & 0.12 & 0.36 & 1.83 & 1 \\
\hline Citus limonia & 1.35 & 0.21 & 0.18 & 1.74 & 2 \\
\hline Faidherbia albida & 0.68 & 0.15 & 0.87 & 1.70 & 2 \\
\hline Schinus molle & 1.01 & 0.15 & 0.05 & 1.22 & 2 \\
\hline Piliostigma thonningii & 1.01 & 0.09 & 0.07 & 1.18 & 1 \\
\hline
\end{tabular}




\begin{tabular}{llllll} 
Delonix regia & 0.68 & 0.12 & 0.20 & 1.00 & 1 \\
Cupressus lusitanica & 0.68 & 0.06 & 0.24 & 0.97 & 1 \\
Arundo donax & 0.34 & 0.48 & 0.05 & 0.87 & 5 \\
Persea americana & 0.34 & 0.27 & 0.26 & 0.87 & 3 \\
Casuarina equisetifolia & 0.34 & 0.03 & 0.19 & 0.56 & 1 \\
Ceiba pentandra & 0.34 & 0.06 & 0.11 & 0.51 & 1 \\
Acacia polycantha & 0.34 & 0.09 & 0.01 & 0.44 & 1 \\
Commiphora africana & 0.34 & 0.03 & 0.02 & 0.39 & 1 \\
\hline & 100.00 & 100.00 & 100.00 & 300.00 & \\
\hline
\end{tabular}

Table 3 Mean diameter abreast height, basal area and stem density for each hoegarden agroforestry size class.

\begin{tabular}{llll}
\hline Homegarden size & DBH(cm) & Basal area $\left(\mathrm{m}^{2} \mathrm{ha}^{-1}\right)$ & Stem density ha ${ }^{-1}$ \\
\hline Small & $15.9(1.3)$ & $17.3(5.5)^{\mathrm{a}}$ & $625.8(125.5)^{\mathrm{a}}$ \\
Medium & $17.0(1.6)$ & $9.1(1.4)^{\mathrm{b}}$ & $309.5(59.4)^{\mathrm{a}}$ \\
Large & $15.3(1.1)$ & $6.9(0.9)_{\mathrm{b}}$ & $337.6(50)^{\mathrm{b}}$ \\
Mean & $16.1(0.8)$ & $11.1(2.0)$ & $424.3(54.4)$ \\
P- Value & Ns & $<0.038$ & $<0.025$ \\
\hline
\end{tabular}

377 Ns - Not significant at 0.05; Standard error of the mean (SE) in parenthesis.

378 Table 4 Non-parametric correlation (Spearman's Rho)

\begin{tabular}{lllllll}
\hline Spearman's Rho & Basal area & Size & $\begin{array}{l}\text { No. } \\
\text { of species }\end{array}$ & Shannon & Trees density & DBH \\
\hline Basal area $\left(\mathrm{ha}^{-1}\right)$ & 1 & & & & \\
Size $\left(\mathrm{ha}^{-1}\right)$ & $-0.46^{* *}$ & 1 & 1 & & \\
No. of species $\left(\mathrm{ha}^{-1}\right)$ & 0.11 & $0.39^{*}$ & 0.10 & $0.68^{* *}$ & 1 & 1 \\
Shannon (H') & 0.29 & $0.52^{* *}$ & $-0.47^{* *}$ & 0.26 & 0.09 & 1 \\
Tree Density $\left(\mathrm{ha}^{-1}\right)$ & $0.62^{* *}$ & -0.03 & -0.04 & 0.24 & -0.04 & 1 \\
DBH (cm) & &
\end{tabular}


$\begin{array}{lllllll}\text { AGB_C Stock (t/ha) } & 0.89 * * & -0.31 & 0.20 & 0.40^{*} & 0.39 * & 0.66^{* *}\end{array}$

$379 * *$ Correlation is significant at the 0.01 level (2-tailed);

$380 *$ Correlation is significant at the 0.05 level (2-tailed)

381 